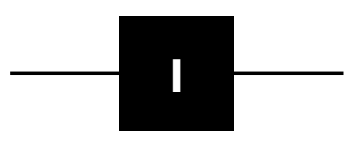

REFLECTIONS

\title{
Rethinking the Anthropology of Violence for the Twenty-First Century
}

\author{
From Practice to Mediation
}

\author{
Antonius C. G. M. Robben
}

Technological developments in the security field are calling for a new anthropological approach to the study of violence. The anthropology of violence shifted during the late 1980s from an emphasis on the structural and symbolic dynamics of violence to a focus on historical and social practices. The concern for violence exercised through political relations was replaced by attention to the everyday experience of violence, while central concepts such as state, power, ritual, mobilization, and resistance made way for terror, trauma, suffering, subjectivity, and resilience. The time has arrived for a new take on violence that can help us understand the revolutionary impact of technological innovations adopted by police, military, secret services, and private companies. The push for seamless surveillance systems, the tapping of e-mail traffic, phone and wireless communications, permanent camera supervision, body scans, biosensors, and activity analyses of cars and people circulating in public places are affecting people's daily lives, bodily integrity, and freedom of personal expression and selfhood. Military operations have become equally invasive with the spread of spy satellites, airborne and submarine drones, and warbots with multiple reconnaissance and combat capabilities. What all these technological developments have in common is a mediation of embodied senses and human decision making. Police and military rely less on their natural senses and professional assessments, and progressively more on mediating devices to control populations and detect suspects and enemies. The ethnographic study of violent social practices should not be abandoned, but new technologies require additional attention to processes of mediation.

Media anthropology and sensory anthropology are two subfields that lend themselves well to the study of mediation processes. Media anthropology is concerned with how certain technologies intervene or mediate in social interaction and cultural production, while sensory anthropology concentrates on the cultural mediation of people's sensorial engagement with the world (Askew and Wilk 2002; Howes 1991; Porcello et al. 2010). Media technologies are situated between sensory perception and the social world, transforming both. The mediation perspective in the anthropology of violence proposed here focuses on this interface between media technologies, sensory perception, and agency as much in daily life as in conflict zones.

Sight has been the privileged sense in security R\&D because visual perception and virtual images occur instantaneously at the speed of light, irrespective of the spatial distance between 
observers and observed. Aural communications continue to be important, and symbiotic systems that interface touch and cognition are gaining in significance (Singer 2010). Sound and chemical detectors, movement sensors, and dogs are also used in contemporary warfare but optical devices are still predominant in military and security forces. The ocularcentrism of Western culture, science, and technology has been criticized convincingly by ethnographic studies of other cultural sensoria and different sensorial classifications and hierarchies (Howes 1991; Ingold 2000; Tyler 1984). Yet these critiques have been verging on culturalism due to their neglect of visual learning, training, and disciplining (Grasseni 2007). Human vision is certainly a historical, social and cultural construct, and sight is generally intertwined with other senses, but when all is said and done, the eye and the ear continue to be natural organs with distinct sensorial properties that engage the world in different, yet cultural ways as the use of electrooptical devices by the military shows.

My interest in the mediation of political violence has focused on the use of night vision equipment in combat operations (Robben 2012, 2013). Military commanders throughout history overlooked the battlefield from a high vantage point and conducted their troops with bugle calls or drum beats. Aerial photography and radar were important optical mediations that replaced a visual inspection of warfighting in the twentieth century (Virilio 1989). In the twenty-first century, commanders and soldiers share a panoptical awareness of the war zone through comprehensive visual and digitized mediation. The latest night vision devices are so sophisticated that they make their users feel close to the real experience of unmediated combat but at the price of drawing soldiers into the logic of immediacy that makes them unaware of the medium through which they perceive reality (Bolter and Grusin 2000). The better the visual mediation of reality becomes, the less soldiers will realize that they see mediated images. Immediacy naturalizes the artificial sight by mistaking enhanced night vision for natural eyesight.

The proliferation of images from drones, thermal imaging, night glow viewers, and satellites further improves the soldier's situational awareness by providing a multidimensional view of the war zone. Mediated warriors are inundated with images that oblige them to navigate through multiple options to arrive at a clear action. This conflation of representation and reality makes soldiers oblivious to visual mediation. Hypermediacy experiences the live multimedia stream as an autonomous sensorium (Bolter and Grusin 1999). The use of networked multisensory devices during combat will only further reinforce such effects when attentiveness and alertness are matters of life or death, and make soldiers prone to rely on computerized judgments through delegated agency. Battle space becomes increasingly virtual through a generative mediation with a distinct visual culture and decision-making process that therefore require urgent research attention in the anthropology of violence.

\section{REFERENCES}

Askew, Kelly, and Richard R. Wilk. 2002. The Anthropology of Media: A Reader. Malden, MA: Blackwell. Bolter, Jay David, and Richard Grusin. 2000. Remediation: Understanding New Media. Cambridge, MA: MIT Press.

Grasseni, Cristina, ed. 2007. Skilled Visions: Between Apprenticeship and Standards. New York: Berghahn Books.

Howes, David, ed. 1991. The Varieties of Sensory Experience: A Sourcebook in the Anthropology of the Senses. Toronto: University of Toronto Press.

Ingold, Tim. 2000. The Perception of the Environment: Essays in Livelihood, Dwelling and Skill. London: Routledge. 
Porcello, Thomas et al. 2010. “The Reorganization of the Sensory World.” Annual Review of Anthropology 39: 51-66.

Robben, Antonius C. G. M. 2012. “The Dead of Night: Chaos and Spectacide of Nocturnal Combat in the Iraq War." Pp. 34-44 in War, Technology, Anthropology, ed. K. Stroeken. New York: Berghahn Books.

Robben, Antonius C. G. M. 2013. “The Hostile Gaze: Night Vision and the Immediation of Nocturnal Combat in Vietnam and Iraq." Pp. 132-151 in Virtual War and Magical Death: Technologies and Imaginaries for Terror and Killing, ed. N. L. Whitehead and S. Finnström. Durham, NC: Duke University Press.

Singer, P. W. 2010. Wired for War: The Robotics Revolution and Conflict in the Twenty-First Century. New York: Penguin.

Tyler, Stephen A. 1984. “The Vision Quest in the West, or What the Mind's Eye Sees." Journal of Anthropological Research 40, no. 1: 23-40.

Virilio, Paul. 1989. War and Cinema: The Logistics of Perception. Trans. Patrick Camiller. London: Verso. 